\title{
PLEURA AND PERITONEUM
}

\section{EDITOR IN CHIEF}

Marc A. Reymond, Tübingen, Germany

\section{ASSOCIATE EDITORS}

Frédéric Bibeau, Montpellier, France

Wim Ceelen, Ghent, Belgium

Ben Davidson, Oslo, Norway

Marc Pocard, Paris, France

Clemens B. Tempfer, Bochum, Germany

\section{EDITORIAL BOARD}

Katalin Dobra, Stockholm, Sweden

Ambrogio Fassina, Padova, Italy

Diane Goéré, Villejuif, France

Sarah Herrick, Manchester, United Kingdom

Kazuho Honda, Tokyo, Japan

Masato Kanzaki, Tokyo, Japan

Kunio Kawanishi, San Diego, CA, USA

Laura Lambert, Worcester, MA, USA

Ulrich Lauer, Tübingen, Germany

Maurie Markman, Philadelphia, PA, USA

Amit Merchea, Jacksonville, FL, USA

Claire W. Michael, Cleveland, OH, USA

Faheez Mohamed, Basingstoke, United Kingdom

Steve Mutsaers, Perth, Australia

Martin K. Oehler, Adelaide, Australia

Kurt Van der Speeten, Genk, Belgium

Wei Peng Yong, Singapore

\section{EXECUTIVE SECRETARY}

Wiebke Solass, Tübingen, Germany

\section{DE GRUYTER}


The publisher, together with the authors and editors, has taken great pains to ensure that all information presented in this work (programs, applications, amounts, dosages, etc.) reflects the standard of knowledge at the time of publication. Despite careful manuscript preparation and proof correction, errors can nevertheless occur. Authors, editors and publisher disclaim all responsibility for any errors or omissions or liability for the results obtained from use of the information, or parts thereof, contained in this work.

The citation of registered names, trade names, trademarks, etc. in this work does not imply, even in the absence of a specific statement, that such names are exempt from laws and regulations protecting trademarks etc. and therefore free for general use.

ISSN 2364-7671 · e-ISSN 2364-768X

All information regarding notes for contributors, subscriptions, Open access, back volumes and orders is available online at www.degruyter.com/pp.

RESPONSIBLE EDITOR Prof. Dr. med. Marc A. Reymond, MD, MBA, Professor of Surgery, Director, PIPAC Program, Department of Surgery and Transplantation, University Hospital, Hoppe-Seyler-Straße 3, 72076 Tübingen, Germany, Tel.: +49 (0)7071 29-86722, Fax: +49 (0)7071 29-5588, Email: marc.reymond@med.uni-tuebingen.de

EXECUTIVE SECRETARY Dr. med. Wiebke Solass, MD, University Hospital Tübingen, Tübingen, Germany, Email: wiebke.solass@t-online.de

JOURNAL MANAGER Heike Jahnke, De Gruyter, Genthiner Straße 13, 10785 Berlin, Germany. Tel.: +49 (0)30 260 05-220,

Fax: +49 (0)30260 05-325, Email: pap.editorial@ degruyter.com

RESPONSIBLE FOR ADVERTISEMENTS Kevin Göthling, De Gruyter, Genthiner Straße 13, 10785 Berlin, Germany. Tel.: +49 (0)30.260 05-170, Email: anzeigen@degruyter.com

TYPESETTING TNQ Technologies, Chennai, India

(C) 2021 Walter de Gruyter GmbH, Berlin/Boston 